\title{
Common and different features of Chinese and Italian hydrogeological mapping guidelines
}

\author{
Wu Aimin ${ }^{1}$, Martarelli Lucio ${ }^{2}$, Ma Rong ${ }^{3}$, Wang Huang ${ }^{1}$, Yang Huifeng ${ }^{3}$ and Bu Hua ${ }^{4}$ \\ ${ }^{1}$ China Geological Survey, Beijing, China (waimin@mail.cgs.gov.cn) \\ ${ }^{2}$ Geological Survey of Italy-ISPRA, Rome, Italy; (lucio.martarelli@isprambiente.it) \\ ${ }^{3}$ Institute of Hydrogeology and Environmental Geology-CAGS, Shijiazhuang, China \\ ${ }^{4}$ South-Shandong Institute of Geo-Engineering Exploration, Yanzhou, China
}

doi: $10.4154 / g c .2018 .07$

Article history:

Manuscript received December 23, 2017 Revised manuscript accepted May 03, 2018 Available online June 21, 2018

\begin{abstract}
The definition of common international guidelines for the compilation of high quality hydrogeological maps has been attempted from the second half of the last century for hydrogeologists, to solve the lack of uniformity among national guidelines due to the various geological-hydrogeological and climatic situations of different countries worldwide.

With this aim, the China Geological Survey and the Geological Survey of Italy-ISPRA are undertaking cooperative research in implementing 1:50,000 scale hydrogeological survey and mapping at selected sites in both countries. The project intends to develop a new generation of hydrogeological and groundwater resource maps with descriptive effectiveness and consistency with field survey data. The project will promote improvements of technologies in hydrogeological survey and mapping of the two countries and might even be agreed at a wider international level.

Chinese and Italian hydrogeological guidelines have similar aspects as well as concerns: 1) the undertaking of field surveys at the 1:50.000 scale and more detailed (1:25000) scale; 2 ) building of a hydrogeological database; 3) publication of the official map in both paper and electronic form; 4) inclusion of several small scale maps inlayed at the margin of a main map in the hydrogeological map layout; 5) comparable level in required survey quota. Furthermore, more attention will be paid to a 3D map, conceptual model, aquifer structure, groundwater cycle and hydrogeological parameter description.

In contrast, the most important difference regards the following. The hydrogeological mapping guidelines of Italy have integrated specifications for both survey and mapping, i.e. they deal with a structural layout characterized by survey contents followed by mapping contents and reflect a technical route of surveying for mapping. In contrast, there are no mapping contents in the current hydrogeological guidelines of China and these then needed to be formulated. The Italian guidelines could provide important references for China in legend organization, mapping rules, survey quota and so on.

Finally, the collaboration between China and Italy is of great significance for the two ancient civilized countries sharing the "One Belt and One Road" international initiative.
\end{abstract}

a final version of the International Legend for Hydrogeological Maps published by IAH in 1995 (STRUCKMEIER \& MARGAT, 1995).

All of these extensively promoted developments of hydrogeological mapping worldwide and were successful. However, these guides and legends are mainly suitable for the compilation of general hydrogeological maps at small-scale, e.g. 1:200.000, 1:500.000 and less. Many medium- and large-scale special purpose maps have been developed at national level, or for selected areas within countries from the second half of the last century. Therefore, the definition of common international guidelines for the compilation of high quality hydrogeological maps at medium- and large-scale has been attempted by hydrogeologists globally, in attempts to solve the lack of uniformity among national guidelines due to the various geological-hydrogeological and climatic situations of different countries.

Hydrogeological map production in Italy is extensive (e.g., GIANNOTTI et al., 1970; PIETRACAPRINA et al., 1980; BONI et al., 1986; CENTAMORE et al., 1991; BOSCHERINI et al., 2005; CELICO et al., 2005; CIVITA et al., 2005) and includes 
studies carried out for many different purposes and at very different reference scales.

Two sheet maps (SERVIZIO GEOLOGICO D'ITALIA, 1973 and 1976) represent early attempts of realizing hydrogeological maps combining hydrogeological thematic elements with geological contents. After 1989, when the New Italian Geological and Geothematic mapping project (CARG project, 1:50.000 scale) began, the first official hydrogeological guidelines to field survey and mapping for the Hydrogeological Map of Italy at 1:50.000 scale were issued by the Geological Survey of Italy (Quaderni, serie III, guidance N.5; SERVIZIO GEOLOGICO NAZIONALE, 1995). They are composed of a standard Legend accompanied with technical specifications about data collection. Nevertheless, they were thought of for manual mapping work, not yet computer assisted. These Italian hydrogeological mapping guidelines follow the general specifications of the International Legend for Hydrogeological Maps, though they adopt specific standards due to the different reference scales and the peculiar and diverse geological and hydrogeological features of the Italian territory. Only one official hydrogeological map sheet (SERVIZIO GEOLOGICO D'ITALIA, 1993) was issued following a preliminary version of the 1995 guidelines, but many non-standard hydrogeological maps published in Italy referred to them with regard to the main aspects.

In 2008 the Geological Survey of Italy (SCALISE \& MARTARELLI, 2008) promoted field testing of the "Guidance N.5" and new guideline proposals were discussed. These tests also started the discussion about digital mapping by the organization of thematic informative layers constituting a GIS. According to these new guideline proposals, four sheet maps are in preparation and a sheet map (CONTE et al., 2016) and a not standard size map (LA VIGNA \& MAZZA, eds., 2015) were realized. Through these field practices, new guideline specifications were gradually improved and an English unpublished provisional version of the Hydrogeological Map of Italy - Guidelines to Survey and Mapping was produced in 2016.

Although China is one of the earliest countries in the world to develop and use groundwater, organized, scientific hydrogeological mapping in China did not start until 1949 when the People's Republic of China was founded. China's hydrogeological mapping can be divided into 2 stages: (1) the period of the Ministry of Geology and Mineral Resources; and (2) the period of the China Geological Survey, Ministry of Land and Mineral Resources.

For the period of Ministry of Geology and Mineral Resources from 1949 to 1998, the basic scale of regional hydrogeological maps has been adopted at 1:200.000. In remote districts or high mountainous regions, where the implementation of geological investigation was difficult, the prevailing scales were $1: 500.000$ to $1: 1.000 .000$. In the 1950s, the hydrogeological map contained more geological factors and fewer hydrogeological elements. People who are not specialists in this subject will have some difficulties in understanding it. Conforming to the principles of simplicity, clarity and practicality, the methods of compilation were improved in the 1960s. Emphasis was placed upon the water storage capacity of water-bearing formations. In the 1970 s, according to the standardized international legends (ANON, 1970) and actual situation in China, the methods of the hydrogeological survey and mapping were continually improved. A set of technical standards for the hydrogeological survey, referring to the plain areas, mountainous areas, karst areas, coastal area, etc. (GEOLOGICAL BUREAU OF NATIONAL PLAN-
NING COMMISSION, 1974, 1975a, 1975b, 1975c, 1978) were developed. In 1993, a new Legend and Colour Standard for the Comprehensive Hydrogeological Map was published (GEOLOGICAL BUREAU OF NATIONAL PLANNING COMMISSION, 1974, 1975a, 1975b, 1975c, 1978; STATE BUREAU OF TECHNICAL SUPERVISION, 1993).

With respect to the second stage, the basic scale of the regional hydrogeological maps has been changed to 1:50.000, from 1999 to the present. To adapt to the new demands of the economic and social developments and the ecological and environmental protections to geological works, four projects on a hydrogeological mapping scale of 1:50.000 have been undergone. The first is the Groundwater Exploration and Water Supply Demonstration in Water Shortage Regions; the second is the Investigation and Assessment of Hydrogeological and Environmental Geology in Karst Regions; the third is the Investigation and Assessment of Hydrogeology in Key Energy Bases; and the fourth is the Investigation and Assessment of Hydrogeological and Environmental Geology in Key Urban Agglomerations.

To obtain high qualities of hydrogeological maps, CGS paid tremendous efforts to formulate a specification of hydrogeological survey at the scale of 1:50.000. China has a territory of 9.6 million $\mathrm{km}^{2}$ with very different hydrogeological characteristics, which are difficult to portray on maps in a set of simple legends and symbols. Although the formulation of the specification commenced in 2006, it was not promulgated until 2015. It experienced complicated procedures, including pre-research, draft version, field trial, revision and improvement (WANG GUILING et al., 2008; WEN DONGGUANG et al., 2012; WU AIMIN et al., 2015). In 2015, the Specification for the Hydrogeological Survey at 1:50.000 promulgated and became effective as a Professional Standard - DZ/T 0282-2015 (THE MINISTRY OF LAND AND MINERAL RESOURCES, 2015).

Only $2.3 \%$ of the whole territory has been completed for this round of hydrogeological mapping at the scale of 1:50.000. For all the map sheets that were completed after 2015, the new specification for hydrogeological mapping was followed; the map sheets that were completed from 2012 to 2014 contributed to the field trial of the specification and to its improvement; and map sheets that were completed before 2011 followed the old specifications for hydrogeological mapping.

Currently, the China Geological Survey (CGS) and Geological Survey of Italy (ISPRA) have respectively implemented projects on hydrogeological survey and mapping at a scale of 1:50.000 and, according to this issue, are carrying out cooperative research aimed at improvements of the technologies and methods. The cooperative project intends to develop a new generation of hydrogeological and groundwater resource maps with descriptive effectiveness and consistency with field survey data. The objectives are: (1) to research the methodology of the 1:50.000 scale hydrogeological survey and mapping; (2) to conduct demonstration and comparative studies on the 1:50.000 scale hydrogeological survey and mapping by selecting sites in both countries with similar hydrogeological conditions and test its applicability; (3) to formulate guidelines on a 1:50.000 scale hydrogeological survey and mapping and promote its standardization. Among these, it constitutes a cornerstone and starting point for cooperative research to compare common and diverse features of Chinese and Italian hydrogeological mapping guidelines.

The pilot areas are: (1) the Luan river plain in the north part of the North China Plain, China; (2) the Rieti Plain, central Italy. 

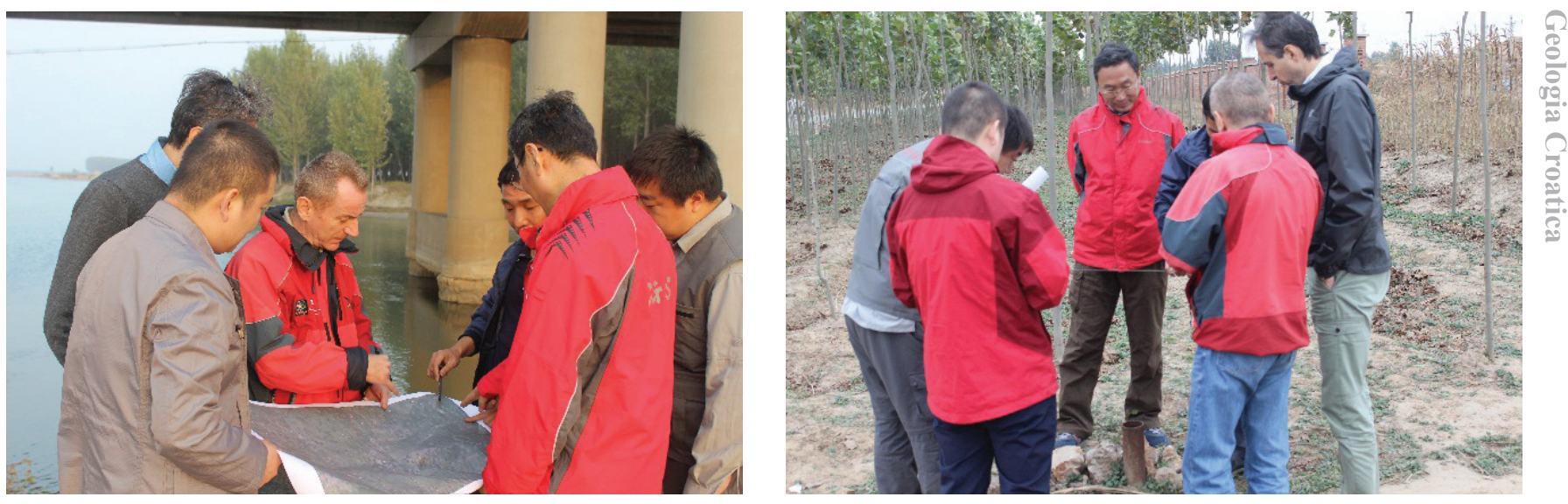

Figure 1. Hydrogeological Survey in China. The Luan River near its mouth (left) and alluvial sediments of the Luan River Plain (right) can be seen in the background.
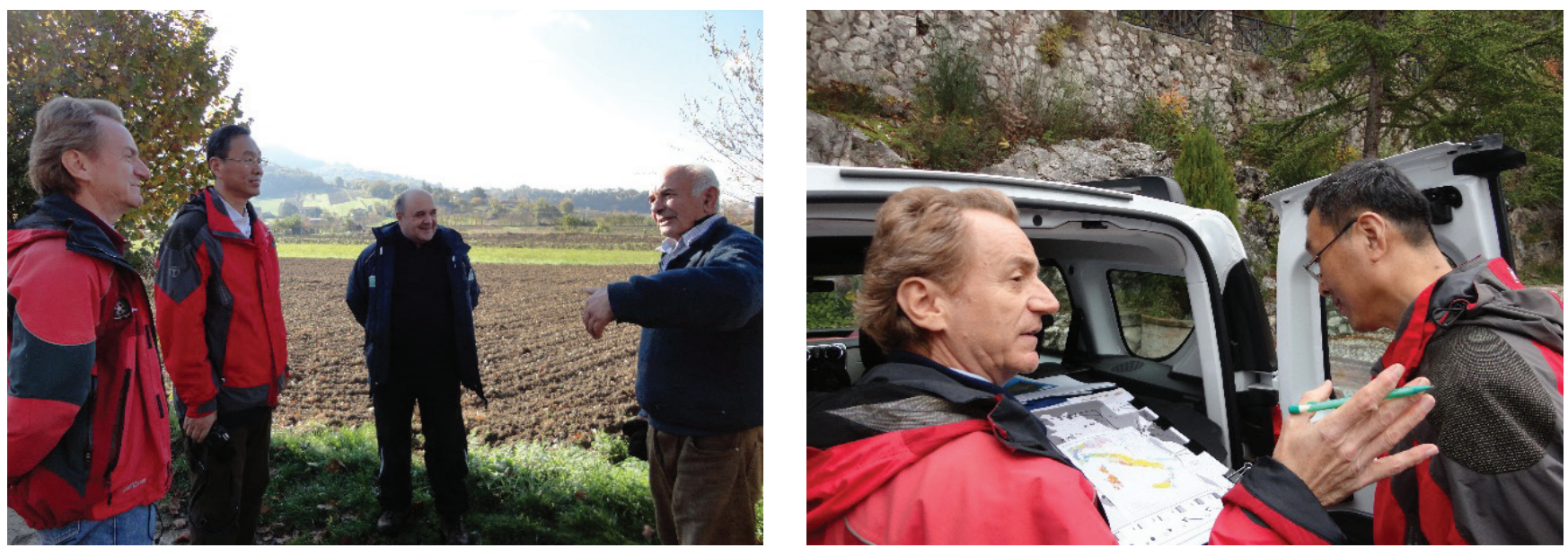

Figure 2. Hydrogeological Survey in Italy. The Rieti Plain landscape (left) and some calcareous rocks cropping out at the Rieti Plain margin (right) can be seen in the background.

Both pilot areas consist of piedmont alluvial-proluvial fans and plains, share similar hydrogeological conditions, and thus will benefit from collaborative and comparative research. In October 2015, ISPRA researchers visited China and attended a field survey to the Luan River plain; CGS researchers showed the hydrogeological survey methods and research findings (Fig. 1). In November 2016, CGS researchers visited Italy and attended a field survey to the Rieti Plain; ISPRA researchers showed some different hydrogeological survey methods, monitoring instruments and mapping findings (Fig. 2). The researchers of both countries have had a deeper understanding of the hydrogeological survey methods and technical standards of both countries.

\section{RESEARCH METHODS AND RESULTS}

The following describes the research methods and results of the comparison between the Hydrogeological Map of Italy - Guidelines to Survey and Mapping, English unpublished version 2016 (here in after referred to as the Italian Guideline) and the Specification for Hydrogeological Survey, DZ/T 0282 - 2015 (hereinafter referred to as the Chinese Guideline). They are identified in 5 respects to better demonstrate the common and different features of both guidelines.

\subsection{Basic requirements}

In the basic requirement for hydrogeological survey and mapping at 1:50.000 scale, both the Chinese and Italian guidelines have almost the same concerns including the following: (1) the geographic map in more detailed scale, normally at 1:25.000 scale; (2) building a hydrogeological database; (3) publication of official maps in both paper and electronic form; (4) several small scale maps inlaid at the margin of a thematic map in hydrogeological map layout; (5) the compilation outline on the specification of the hydrogeological map; (6) more attention paid to a 3D map, conceptual model, aquifer structure, groundwater cycle and hydrogeological parameter description.

\subsection{General layout of hydrogeological map}

Chinese guideline and Italian guideline have mostly the same concerns in the layout of the hydrogeological map. Both guidelines stipulate that a hydrogeological map should be composed of the following basic elements: (1) map heading and editorial information, (2) a hydrogeological thematic map, (3) hydrogeological cross-section maps, (4) hydrogeological complex columns, (5) hydrogeological perspective and small scale insets, (6) legends and symbols, etc.

There are only a few differences between them. For the Chinese guideline, legends are placed on the right of the map and hydrogeological complex columns are put on the left; for the Italian guideline, legends are on the left with hydrogeological complex columns on the right. The general layout of the hydrogeological map in the Italian guideline is shown in Fig. 3. 


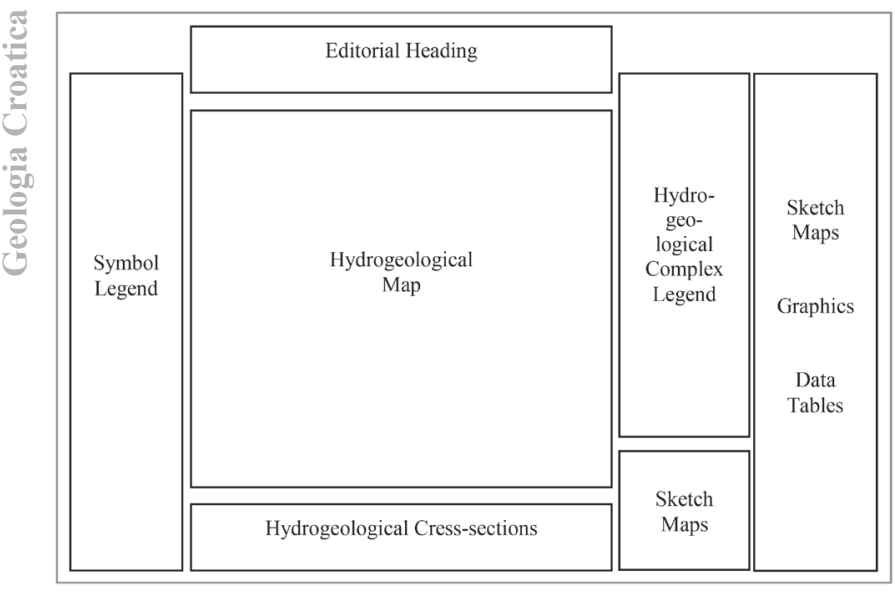

Figure 3. A demonstration of hydrogeological map layout. Among the basic elements are: map heading and editorial information, a hydrogeological thematic map, hydrogeological cross-sections, hydrogeological complex columns, hydrogeological small scale insets, legends, symbols, etc.

\subsection{Structure tree of legends and symbols}

The Italian guideline comprises eight tables from which to reflect and choose the legend structure and its caption. Each table indicates rules and specifications portraying features on the kind of hydrogeological characters expected.

(1) Table A describes the surface hydrology. It deals with rivers, lakes, wetland, swamps and reservoirs, and also characterizes the attributes of rivers and the relationship between rivers and groundwater.

(2) Table B describes the groundwater hydrology. It reflects the attributes of groundwater, including groundwater emergences, aquifer features, hydrodynamic features, and hydrochemical features.

(3) Table C describes hydrogeological complexes distinguished on the relative degree of permeability. Four degrees of relative permeability were defined (high permeability complexes, AP; intermediate permeability complexes, MP; scarce permeability complexes, SP; very low permeability complexes, BP) according to parameters including grain size, fissuration index, karst index, specific yield (or annual mean groundwater flow, in $\mathrm{m}^{3} / \mathrm{a} / \mathrm{km}^{2}$ ) and in particular in comparison to the hydrogeological features of adjacent complexes.

(4) Table D describes the artificial works for water abstraction. Only the main or relevant water supply works, wells and hydraulic works have to be represented on the hydrogeological map.

(5) Table E describes the karst area. It is dedicated to the symbols regarding the most significant karst morphologies such as dolines, sinkholes and caves.

(6) Table F describes the lithological symbols. This table includes thirty symbols, which involve sedimentary rock, volcanic rock and metamorphic rock. It emphasizes the sedimentary rock and unconsolidated sediment with stronger water abundance.

(7) Table G describes the hydrogeological boundaries and other boundary typologies of hydrogeological relevance. This table includes three boundaries: infiltration waters totally or partially pass through the limit; flowing groundwater passes through the limit under the saturation sur- face elevation; and the limit occurs at the contact between permeable and impermeable/very low permeable rocks.

(8) Table $\mathrm{H}$ describes hydrogeological complexes. It stipulates how to distinguish hydrogeological complexes by effective infiltration and transmissivity. For example, according to the effective infiltration, the complexes are distinguished into three types (i.e. covering deposits; sedimentary deposits; volcanic and metamorphic rocks) and the covering deposits may also be divided into four groups according to their effective infiltration values.

Comparison with the Italian guideline shows that the Chinese guideline does not give the specifications for the compilation of a hydrogeological map. The current Chinese guideline is only a hydrogeological survey guideline, rather than a mapping guideline. The Legend and Colour Standard for the Comprehensive Hydrogeological Map (STATE BUREAU OF TECHNICAL SUPERVISION, 1993) can be used for guiding the hydrogeological map, but it is special for the 1:200.000 scale, only partly suitable to 1:50.000 scale. Based on the Italian guideline and the Legend and Colour Standard for Comprehensive Hydrogeological Map, at present, the China Geological Survey is formulating a guideline for the compilation of a hydrogeological map at a 1:50.000 scale. A draft version of these guideline proposals has been completed and, according to them, a hydrogeological map draft in a pilot area of China is shown in Figure 4.

\subsection{Field workload quota}

The Chinese guideline defines the field workload quota in a longer table in detail (Table 1), while the Italian guideline also defines them in a shorter table in brief (Table 2).

Some work items, such as survey points, water level points and water sampling points, are listed in both guidelines and with comparability in the workload quotas. Some work items, such as survey route intervals, geophysical exploration profiles and exploration boreholes, only appear in the Chinese guideline. Some work items, such as transmissivity/hydraulic conductivity tests, spring/karst inflow-outflow points, river flowrate tests, only appear in the Italian guideline. Since the aim of the research is not the definition of the best methodology for the acquisition of the aforementioned survey parameters but the necessity of their availability, it is assumed that each parameter listed in both tables 1 and 2 may be estimated by different criteria (e.g.: hydraulic conductivity from grain size, pumping test data, soil mechanic lab tests, etc.; water level measurements by manual or time continuous data-logging instruments; river flowrate and spring discharge measurements in temporary or permanent stations by volumetric tests, flow meter or other gauging devices; water sampling for chemical analyses by diverse methods; geophysical exploration profiles using various methodologies).

The different requirements of field workload quota in the Chinese and Italian guidelines reflect the different philosophies for hydrogeological survey and mapping in both countries. The Chinese guideline pays more attention to the exploration of aquifer structures (and therefore geophysical surveys and exploration boreholes are expressly requested), while the Italian guideline pays more attention to the acquisition of hydrogeological parameters (transmissivity/hydraulic conductivity, spring/ karst inflow-outflow and river flowrate tests are requested). The Chinese guideline reflects the high equipment capability and technological skills available at the CGS. 


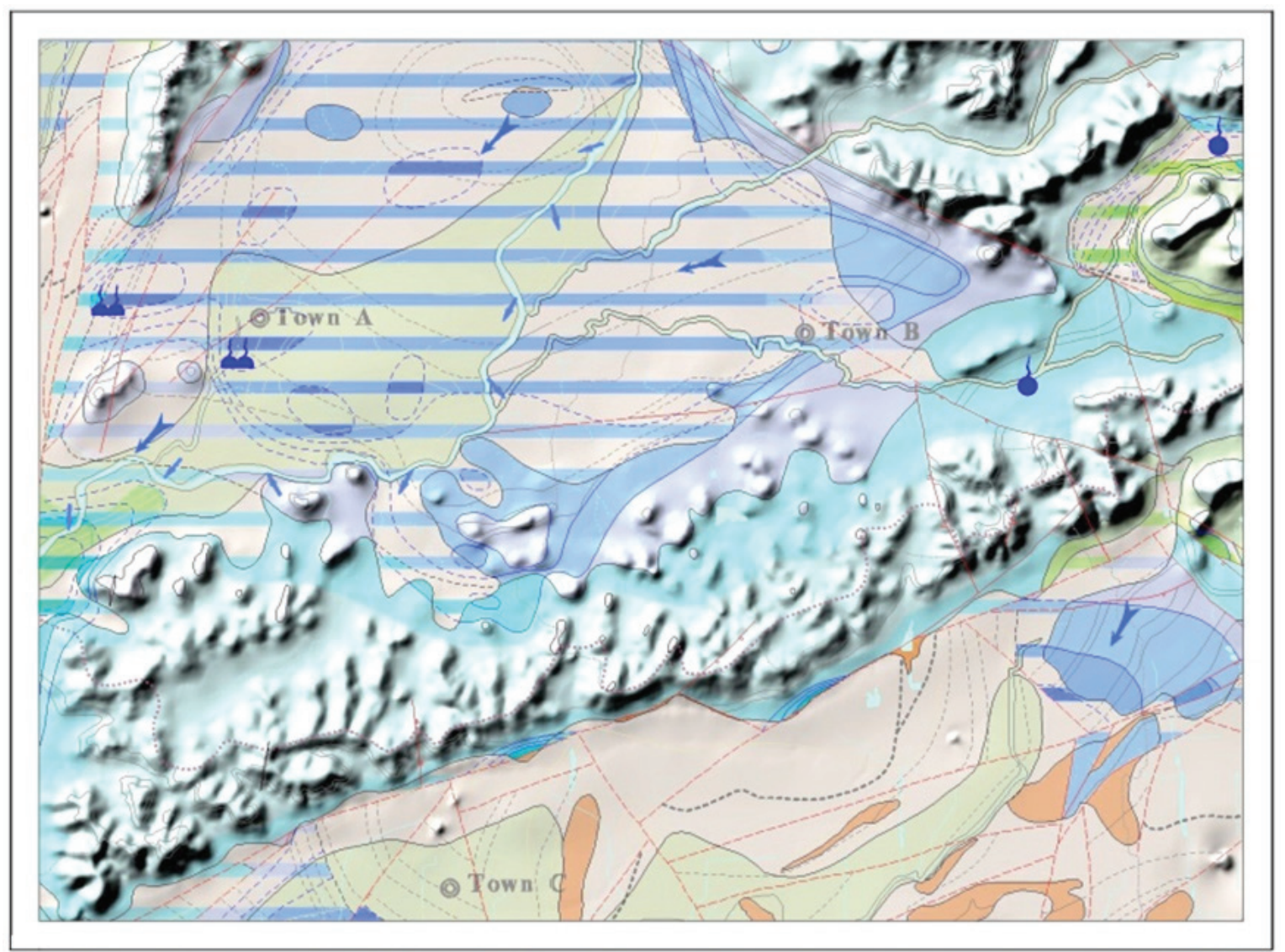

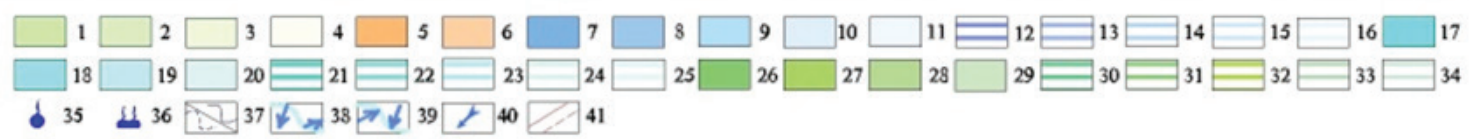

Figure 4. A thematic map demonstration of a hydrogeological map draft in a mapping area of China according to the new compilation proposals at a 1:50.000 scale. The legend symbols can be divided into four groups according to the hydrogeological features they represent. The first group includes 4 that show the productivity of pore aquifers in unconsolidated rocks; 1 . flow rate of a single well $300-1000 \mathrm{~m}^{3} / \mathrm{d} ; 2$. flow rate $100-300 \mathrm{~m}^{3} / \mathrm{d} ; 3$. flow rate $<100 \mathrm{~m}^{3} / \mathrm{d} ; 4$. flow rate $<100 \mathrm{~m}^{3} / \mathrm{d}$. The second group shows the productivity of pore-fracture aquifers in clastic rocks and includes 2 symbols; 5 . flow rate $<10 \mathrm{~m}^{3} / \mathrm{d} ; 6$. flow rate $10-100 \mathrm{~m}^{3} / \mathrm{d}$. The third group shows the productivity of karst cave-fracture aquifers in carbonate rocks and includes 28 symbols; Ordovician systems, exposed type: 7 . flow rate $>5000 \mathrm{~m}^{3} / \mathrm{d}$; 8 . flow rate $1000-5000 \mathrm{~m}^{3} / \mathrm{d} ; 9$. the flow rate $300-1000 \mathrm{~m}^{3} / \mathrm{d} ; 10$. flow rate $100-300 \mathrm{~m}^{3} / \mathrm{d} ; 11$. flow rate $<100 \mathrm{~m}^{3} / \mathrm{d}$. Ordovician systems, covered type: 12 . flow rate $>5000 \mathrm{~m}^{3} / \mathrm{d} ; 13$. flow rate $1000-5000 \mathrm{~m}^{3} / \mathrm{d} ; 14$. flow rate $100-300 \mathrm{~m}^{3} / \mathrm{d} ; 16$. flow rate $<100 \mathrm{~m}^{3} / \mathrm{d}$. Upper-Middle Cambrian system, exposed type: 17 . flow rate $1000-$ $5000 \mathrm{~m}^{3} / \mathrm{d}$; 18 . flow rate $300-1000 \mathrm{~m}^{3} / \mathrm{d} ; 19$. flow rate $100-300 \mathrm{~m}^{3} / \mathrm{d} ; 20$. flow rate $<100 \mathrm{~m}^{3} / \mathrm{d}$. Upper-Middle Cambrian system, covered type: 21 . flow rate $>5000$ $\mathrm{m}^{3} / \mathrm{d} ; 22$. flow rate $1000-5000 \mathrm{~m}^{3} / \mathrm{d} ; 23$. flow rate $300-1000 \mathrm{~m}^{3} / \mathrm{d} ; 24$. flow rate $100-300 \mathrm{~m}^{3} / \mathrm{d} ; 25$. flow rate $<100 \mathrm{~m}^{3} / \mathrm{d}$. Lower Cambrian system, exposed type: 26 . flow rate $1000-5000 \mathrm{~m}^{3} / \mathrm{d} ; 27$. flow rate $300-1000 \mathrm{~m}^{3} / \mathrm{d} ; 28$. flow rate $100-300 \mathrm{~m}^{3} / \mathrm{d} ; 29$. flow rate $<100 \mathrm{~m}^{3} / \mathrm{d}$. Lower Cambrian system, covered type: 30 . flow rate $>5000 \mathrm{~m}^{3} / \mathrm{d} ; 31$. flow rate $1000-5000 \mathrm{~m}^{3} / \mathrm{d} ; 32$. flow rate $1000-5000 \mathrm{~m}^{3} / \mathrm{d} ; 33$. flow rate $100-300 \mathrm{~m}^{3} / \mathrm{d} ; 34$. flow rate $<100 \mathrm{~m}^{3} / \mathrm{d}$. The fourth group shows the typical hydrogeological features that influence and control the formation and movement of the regional groundwater and includes 7 symbols; 35 . ascending spring; 36. seasonal spring group; 37 . boundary of aquifer; 38. groundwater recharge from river; 39. groundwater discharge into river; 40 . groundwater flow direction; 41 . fault.

In any case, it is finally observed that an opportune assessment on typology and the distribution of surveys for any hydrogeological mapping purposes is in direct connection with the strategic importance of the groundwater resources of the region which is being mapped.

\subsection{Items to be surveyed}

In the Chinese guideline, a large number of words are used to define the common requirements for a field hydrological survey, covering the structure of unsaturated zones, the spatial structure of aquifers and water-bearing formations, parameters of aquifers and water-bearing formations, groundwater system boundary, recharge runoff discharge conditions of groundwater, dynamic characteristics of groundwater, chemical characteristics of groundwater, development and utilization of groundwater, environmental geological problems related to groundwater, special groundwater. Another significant part is used to define the special requirements for a hydrological survey in the plain and basin area, mountain and hilly area, and karst area.

The Italian guideline deals with a structural layout characterized by survey contents followed by mapping contents. It reflects a technical route in which the field surveying serves as a compilation for the hydrogeological map and the survey contents should tightly grasp the needs of compilation of the hydrogeological maps. The survey requirements include surface water hydrology, groundwater hydrology, characteristics of groundwater hydraulics, characteristics of groundwater chemistry, effective infiltration, groundwater conductivity, etc.

\section{NEXT STEP OF THE PROJECT}

As a next step, CGS and ISPRA will jointly compile the hydrogeological maps for each of the pilot areas using both methodologies, thus adopting the advantages of both sets of guidelines, in accordance with international conventions. The aim is to 
Table 1. Field workload quota in Chinese guideline (unless specified, values refers to number of required survey points per $100 \mathrm{~km}^{2}$ ).

\begin{tabular}{|c|c|c|c|c|c|c|c|c|}
\hline $\begin{array}{l}\text { Types of } \\
\text { survey area }\end{array}$ & & $\begin{array}{l}\text { Survey route } \\
\text { Interval } \\
(\mathrm{km})\end{array}$ & Survey points & Water level points & $\begin{array}{l}\text { Geophysical } \\
\text { exploration } \\
\text { profiles }(\mathrm{km})\end{array}$ & $\begin{array}{l}\text { Unsteady flow } \\
\text { pumping tests }\end{array}$ & $\begin{array}{c}\text { Exploration } \\
\text { boreholes }\end{array}$ & $\begin{array}{c}\text { Water sampling } \\
\text { points }\end{array}$ \\
\hline & Simple area & $1.7 \sim 2.0$ & $40 \sim 55$ & $8 \sim 10$ & $12 \sim 15$ & $1 \sim 2$ & $1.5 \sim 2$ & $6 \sim 8$ \\
\hline \multirow[t]{3}{*}{ Plain Basin } & Medium area & $1.5 \sim 1.7$ & $55 \sim 65$ & $10 \sim 12$ & $15 \sim 18$ & $1 \sim 3$ & $2 \sim 3$ & $8 \sim 12$ \\
\hline & Complex region & $1.2 \sim 1.5$ & $65 \sim 70$ & $12 \sim 16$ & $18 \sim 20$ & $1 \sim 4$ & $3 \sim 4$ & $12 \sim 26$ \\
\hline & Simple area & $1.2 \sim 1.5$ & $45 \sim 55$ & $6 \sim 8$ & $2 \sim 5$ & $1 \sim 2$ & $1.5 \sim 2$ & $4 \sim 6$ \\
\hline \multirow[t]{3}{*}{ Mountain and hill } & Medium area & $0.9 \sim 1.2$ & $55 \sim 80$ & $8 \sim 10$ & $3 \sim 5$ & $1 \sim 3$ & $2 \sim 3$ & $6 \sim 8$ \\
\hline & Complex region & $0.6 \sim 0.9$ & $80 \sim 120$ & $10 \sim 12$ & $4 \sim 6$ & $1 \sim 5$ & $3 \sim 5$ & $8 \sim 12$ \\
\hline & Simple area & $1.2 \sim 1.5$ & $40 \sim 60$ & $8 \sim 10$ & $2 \sim 5$ & $1 \sim 2$ & $1.5 \sim 2$ & $5 \sim 8$ \\
\hline \multirow[t]{2}{*}{ Karst region } & Medium area & $0.9 \sim 1.2$ & $60 \sim 90$ & $10 \sim 14$ & $3 \sim 5$ & $1 \sim 3$ & $2 \sim 3$ & $8 \sim 12$ \\
\hline & Complex region & $0.6 \sim 0.9$ & $90 \sim 130$ & $14 \sim 18$ & $4 \sim 6$ & $1 \sim 5$ & $3 \sim 5$ & $12 \sim 18$ \\
\hline
\end{tabular}

Table 2. Field workload quota in Italian guideline (values refers to number of required survey points per $100 \mathrm{~km}^{2}$ ).

\begin{tabular}{|c|c|c|c|c|c|c|}
\hline $\begin{array}{l}\text { Types of } \\
\text { survey area }\end{array}$ & $\begin{array}{l}\text { Survey } \\
\text { points }\end{array}$ & $\begin{array}{l}\text { Water level } \\
\text { points }\end{array}$ & $\begin{array}{l}\text { Transmissivity/hydraulic } \\
\text { conductivity tests }\end{array}$ & $\begin{array}{c}\text { Spring/karst } \\
\text { inflow-outflow points }\end{array}$ & $\begin{array}{l}\text { River flowrate } \\
\text { tests }\end{array}$ & $\begin{array}{l}\text { Water sampling } \\
\text { points }\end{array}$ \\
\hline Plain & $50 \sim 70$ & $20 \sim 25$ & $10 \sim 15$ & $0 \sim 5$ & $20 \sim 25$ & $10 \sim 15$ \\
\hline Karst region & $50 \sim 70$ & $10 \sim 15$ & $0 \sim 5$ & $30 \sim 35$ & $10 \sim 15$ & $10 \sim 15$ \\
\hline
\end{tabular}

achieve the goal to translate the hydrogeological setting into a visual representation which can be understood without error and bias by the map user; and more straightforwardly, to develop a profound grasp of the complex hydrogeological situation and to portray it in a clear and easily readable manner on a map.

\section{CONCLUSIONS}

Chinese and Italian guidelines have some common features including the graphic map at a scale of 1:50.000, the building of a hydrogeological database, publication of the official map in both paper and electronic form, general layout of hydrogeological map, comparable levels of the amount of survey data required. Furthermore, more attention will be paid to a 3D map, conceptual model, the aquifer structure, groundwater cycle and hydrogeological parameter description.

In addition there are also some differences including the guideline structure, some survey content, and some field workload quotas. The most important point is that the Italian guideline is an integrated guideline both for surveying and for mapping; while the Chinese guideline is only for the hydrogeological survey. The China Geological Survey is now formulating a hydrogeological mapping guideline at 1:50.000 scale.

In the coming years, the CGS and ISPRA will combine the advantages of the Chinese and Italian guidelines to establish a new guideline for hydrogeological mapping at 1:50.000 scale, which will benefit both China and Italy, as well as other nations around the globe.

The collaboration on hydrogeological mapping between China and Italy is of great significance for the two ancient civilized countries sharing the "One Belt and One Road" international initiative.

\section{ACKNOWLEDGEMENT}

This work is jointly supported by the China Geological Survey and the Geological Survey of Italy-ISPRA. This paper is dedicated to Mr Giovanni CONTE who produced some parts of the draft paper, and who unfortunately died in a traffic accident in January, 2016 in Rome.

\section{REFERENCES}

ANON (1963): International Legend for Hydrogeological Maps.- UNESCO, Paris, Document NS/NR/20, $32 \mathrm{p}$.

ANON (1970): International Legend for Hydrogeological Maps.- UNESCO, Paris. Cook, Hammond \& Kell Ltd., England, 101 p. (text in English, French, Spanish and Russian).

BONI, C.F., BONO, P. \& CAPELLI, G. (1986): Schema idrogeologico dell'Italia centrale "Hydrogeological sketch map of central Italy".-- Memorie Società Geologica d'Italia, 35, 991-1012.

BOSCHERINI, A., CHECCUCCI, R., NATALE, G. \& NATALI, N. (2005): Carta Idrogeologica della Regione Umbria (scala 1:100.000) "Hydrogeological Map of Umbria Region (1:100.000 scale)".- Giornale di Geologia Applicata 2.

CELICO, P.B., DE VITA, P., MONACELLI, G., SCALISE, A.R. \& TRANFAGLIA, G. (2005): Carta idrogeologica dell'Italia Meridionale scala 1:250.000 "Hydrogeological Map of southern Italy at 1:250.000 scale".- ISPRA, Rome, Italy.

CENTAMORE, E., PANBIANCHI, G., DEIANA, G., CALAMITA, F., CELlO, G., DRAMIS, F., GENTILI, B. \& NANNI, T. (1991): Ambiente fisico delle Marche. Geologia, Geomorfologia, Idrogeologia (scala 1:100.000) "Physical environment of Marche. Geology, Geomorphology, Hydrogeology (1:100.000 scale)".- Regione Marche.

CIVITA, M., LO RUSSO, S. \& VIGNA, B. (2005): Carta Idrogeologica schematica del Piemonte (NW Italia) (scala 1:250.000) "Hydrogeological sketch map of Piedmont (NW Italy) (1:250.000 scale)".- CNR-GNDCI/Politecnico di Torino, Firenze, Italy.

CONTE, G., MARTARELLI, L., MONTI, G.M., MOTTERAN, G., SCALISE, A.R., SERAFINI, R. \& SILVI, A. (2016): Caratteristiche idrogeologiche dell'area del Foglio 348 Antrodoco alla scala 1:50.000 "Hydrogeological features of the Sheet N.348 Antrodoco area, 1:50.000 scale".- Memorie Descrittive della Carta Geologica d'Italia.

GEOLOGICAL BUREAU OF NATIONAL PLANNING COMMISSION (1974): Technical regulation of regional hydrogeological survey in karst areas.- The People's Republic of China, Beijing (in Chinese).

GEOLOGICAL BUREAU OF NATIONAL PLANNING COMMISSION (1975a): Technical regulation of regional hydrogeological survey in plain areas.- The People's Republic of China, Beijing (in Chinese).

GEOLOGICAL BUREAU OF NATIONAL PLANNING COMMISSION (1975b): Technical regulation of regional hydrogeological survey in mountainous areas.The People's Republic of China, Beijing (in Chinese).

GEOLOGICAL BUREAU OF NATIONAL PLANNING COMMISSION (1975c): Technical regulation of regional hydrogeological survey in coast areas.- The People's Republic of China, Beijing (in Chinese).

GEOLOGICAL BUREAU OF NATIONAL PLANNING COMMISSION (1978): Compilation method of comprehensive hydrogeological map.- The People's Republic of China Beijing (in Chinese).

GIANNOTTI, G.P., LOMBARDI, L. \& SIDO, G. (1970): Carta idrogeologica della Sicilia sud occidentale (scala 1:200.000) "Hydrogeological Map of south-western Sicily (1:200.000 scale)".- Comitato Nazionale Energia Nucleare - Laboratorio Geomineralogico. 
LA VIGNA, F. \& MAZZA, R (eds.) (2015): Hydrogeological map of Rome - 1:50.000 scale.- PO.LI.GRAF., Pomezia, Rome, Italy.

MINISTRY OF LAND AND MINERAL RESOURCES (2015): Specification for hydrogeological survey 1:50,000.- DZ/T 0282-2015. The People's Republic of China (in Chinese).

PIETRACAPRINA, A., DETTORI, B. \& MOUTON, J. (1980): Carta delle risorse idriche della Sardegna alla scala 1:250.000. Schema Idrogeologico "Groundwater Resource Map of Sardinia at 1:250.000 scale. Hydrogeological Sketch".- In: "Ricerche idriche sotterranee in Sardegna". Università degli Studi di Sassari-Cassa per il Mezzogiorno, Progetto speciale 25.

SCALISE, A.R., MARTARELLI, L. (eds.) (2008): Studi sperimentali finalizzati alla cartografia idrogeologica "Field surveys for the implementation of the hydrogeological cartography".-- Memorie Descrittive della Carta Geologica d'Italia, LXXXI, 176 p.

SERVIZIO GEOLOGICO D'ITALIA (1973): Carta idrogeologica alla scala 1:50.000 F.611 Mistretta "Hydrogeological Map at 1:50.000 scale - Sheet N.611 Mistretta".- IPZS, Rome, Italy.

SERVIZIO GEOLOGICO D'ITALIA (1976): Carta idrogeologica alla scala 1:50.000 F.291 Pergola "Hydrogeological Map at 1:50.000 scale - Sheet N.291 Pergola".IPZS, Rome, Italy.

SERVIZIO GEOLOGICO D'ITALIA (1993): Carta idrogeologica alla scala 1:50.000 F.389 Anagni "Hydrogeological Map at 1:50.000 scale - Sheet N.389 Anagni".IPZS, Rome, Italy.
SERVIZIO GEOLOGICO NAZIONALE (1995): Carta Idrogeologica d'Italia 1:50.000. Guida al rilevamento e alla rappresentazione "Hydrogeological Map of Italy 1:50.000. Guideline to survey and mapping”.- Quad. SGN n.5, serie III, IPZS, Rome, Italy.

STATE BUREAU OF TECHNICAL SUPERVISION (1993): Legend and color standard for comprehensive hydrogeological map.- GB/T 14538-93. The People's Republic of China, Beijing (in Chinese).

STRUCKMEIER, W.F., MONKHOUSE, R.A., JELGERSMA, S. \& GILBRICH, W.H. (1983): International Legend for Hydrogeological Maps (revised edition).- UNESCO, Paris.

STRUCKMEIER, W.F. \& MARGAT, J. (1995): Hydrogeological maps. A guide and a standard legend.- International Contribution to Hydrogeology, 17, 77 p. IAH. Verlag Heinz Heise, Hannover, Germany.

WANG, G. \& YANG, H. (2008): The Report on Hydrogeological Survey of Selected Typical Regions at 1:50.000.- The Institute of Hydrogeology and Environmental Geology, CAGS, Shijiazhuang (in Chinese).

WEN, D., WANG, G., ZHANG, E. \& YANG, H. (2012): The specification for hydrogeological survey 1:50.000 - Trial Version.- China Geological Survey, Beijing (in Chinese).

WU, A., WANG, G. \& YANG, H. (2015): The explanation on formulating specification for hydrogeological survey 1:50.000.- China Geological Survey, Beijing (in Chinese). 
